\title{
Implementasi Metode Fuzzy Logic Pada Intensitas Lampu di Laboratorium Berbasis Arduino
}

\author{
Afdal Alhafiz \\ Program Studi Sistem Komputer, STMIK Triguna Dharma \\ J1. A.H Nasution No.73 Medan, Indonesia, 20142
}

\begin{tabular}{|c|c|}
\hline Article Info & ABSTRACT \\
\hline $\begin{array}{l}\text { Article history: } \\
\text { Received Jul } 15^{\text {th }}, 2020 \\
\text { Revised Jul 22 } 2^{\text {th }}, 2020 \\
\text { Accepted Aug } 12^{\text {th }}, 2020\end{array}$ & $\begin{array}{l}\text { Lampu adalah sumber penerangan yang digunakan pada saat kondisi ruangan } \\
\text { gelap. Penerangan ruangan berpengaruh terhadap penglihatan manusia dalam } \\
\text { mengenali objek tertentu. Sebenarnya penggunaan lampu otomatis sudah } \\
\text { diterapkan pada beberapa tempat atau lokasi, namun penggunaanya belum } \\
\text { terlalu efektif. Maka dari itu dilakukan penelitian untuk mengatur nyala dan } \\
\text { padamnya lampu serta mengotomatisasi intensitas lampu yang dapat }\end{array}$ \\
\hline $\begin{array}{l}\text { Keyword: } \\
\text { Arduino Uno } \\
\text { Sensor PIR } \\
\text { Sensor LDR } \\
\text { Logika Fuzzy } \\
\text { Lampu LED }\end{array}$ & $\begin{array}{l}\text { menyesuaikan kebutuhan gelap terangnya sesuai dengan keadaan ruangan. } \\
\text { Pada penelitian ini, sistem diterapkan menggunakan sensor PIR sebagai } \\
\text { pendeteksi objek manusia dan sensor LDR sebagai pendeteksi intensitas } \\
\text { cahaya di luar ruangan. Pengendali yang digunakan adalah Arduino uno yang } \\
\text { berfungsi sebagai pemproses sinyal masukan dari sensor dengan algoritma } \\
\text { logika Fuzzy yang kemudian menghasilkan keluaran yang dapat mengatur } \\
\text { intensitas lampu. Hasil dari pengujian terhadap metode ini adalah Intensitas } \\
\text { cahaya yang dihasilkan dari nyala lampu LED berbaur dengan cahaya dari luar } \\
\text { sehingga menghasilkan cahaya ruang. kinerja dari Alat Kendali Penerangan } \\
\text { laboratorium dengan Logika Fuzzy Berbasis Arduino uno telah bekerja dengan } \\
\text { baik, sistem dapat membaca intensitas cahaya di luar ruangan laboratorium } \\
\text { kemudian diolah oleh arduino uno dengan algoritma pemrograman Logika } \\
\text { Fuzzy selanjutnya diperoleh output dari Logika Fuzzy yang berupa pengaturan } \\
\text { tegangan menggunakan teknik PWM sehingga dapat mengatur cahaya yang } \\
\text { dikeluarkan oleh lampu LED. }\end{array}$ \\
\hline
\end{tabular}

Copyright (C) 201x STMIK Triguna Dharma. All rights reserved.

Corresponding Author: *First Author

Nama : Afdal Al Hafiz

Program Studi : Sistem Komputer

STMIK Triguna Dharma

\section{PENDAHULUAN}

Penerangan mempunyai pengaruh terhadap penglihatan manusia. Pengaturan intensitas lampu dimaksudkan untuk memberikan pencahayaan yang optimal terhadap objek dan keadaan di sekelilingnya. Umumnya sistem pencahayaan yang ada saat ini menggunakan saklar on dan off dimana saat ruangan gelap lampu dinyalakan dan di saat ruangan terang lampu dimatikan. Banyak penelitian yang dilakukan pada sistem penerangan, dimana pengaturan penerangan hanya berdasarkan kondisi gelap ataupun terang. Sementara itu untuk intensitas kecerahan lampu masih jarang diimplementasikan.

Penelitian yang akan dilakukan berpusat pada pengaturan intensitas cahaya lampu laboratorium berdasarkan konstribusi cahaya dari luar. Laboratorium yang dimaksud disini adalah ruangan yang memiliki akses cahaya luar sehingga untuk kedepannya sistem penerangan akan lebih efektif dan efisien. Metode yang akan digunakan adalah metode Fuzzy Logic, di mana metode ini akan dikombinasikan serta diimplementasikan ke dalam mikrokomputer yakni Mikrokontroller Arduino.

\section{METODE PENELITIAN}

Metode penelitian merupakan kaidah yang harus dilakukan dalam sebuah penelitian. Hal ini dimaksudkan agar hasil yang diperoleh dari penelitian lebih maksimal. Dan yang termasuk di dalam metodologi penelitian 
salah satunya adalah kerangka kerja, baik kerangka kerja sistem yang akan dihasilkan maupun prosedur aritmatik yang terdapat di dalam sistem. Tujuan dari metodologi penelitian yang lain adalah membuat sistem yang lebih terstruktur.

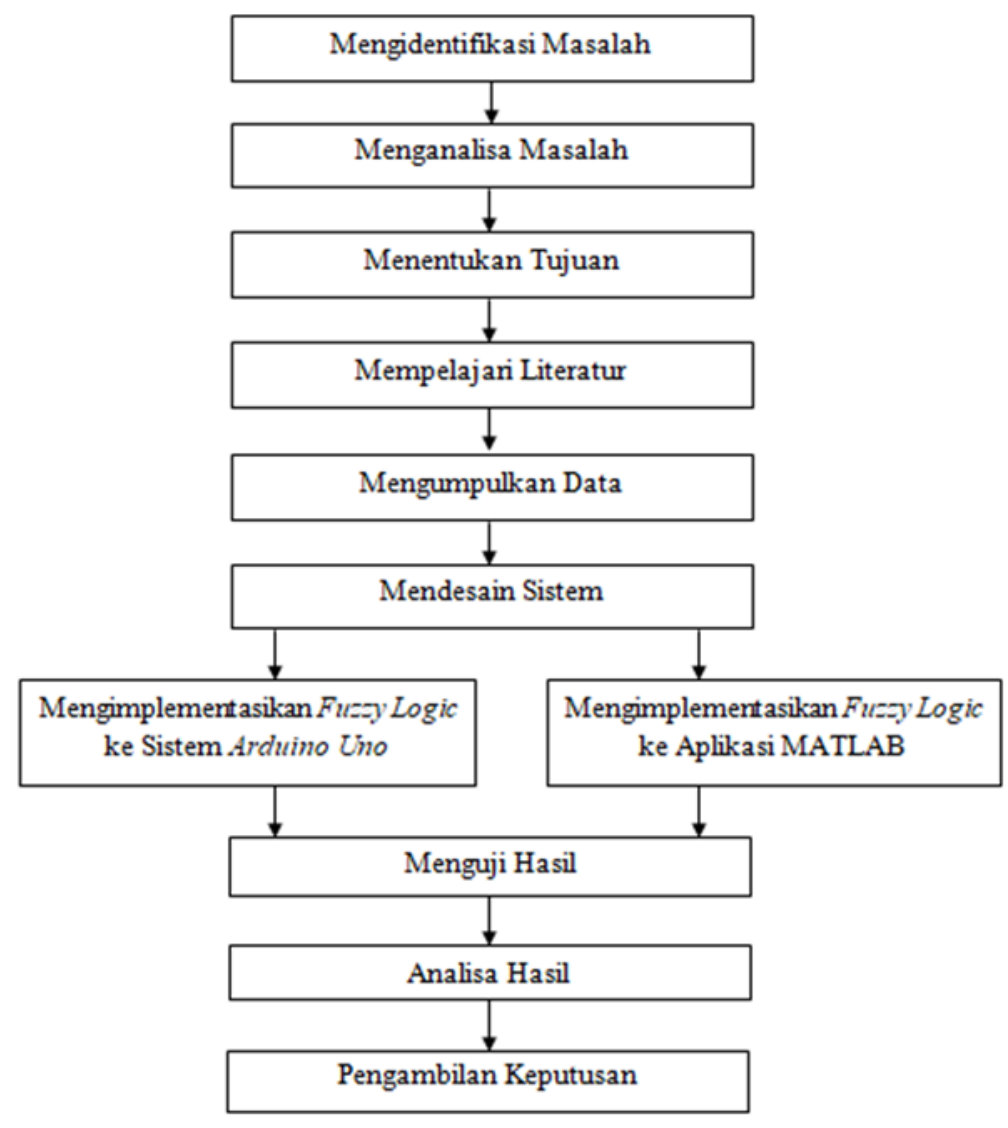

Gambar 1 Kerangka Kerja

Berdasarkan gambar 1 maka dapat dijabarkan langkah langkah kerja penelitian sebagai berikut :

1. Mengidentifikasi masalah

Masalah yang diidentifikasi dalam penelitian ini adalah kesulitan dalam mengimplementasikan metode sistem dan matematis ke dalam hardware yakni mikrokontroler.

2. Menganalisa masalah

Analisa yang akan dilakukan dalam penelitian ini adalah algoritma dalam menentukan tingkat intensitas cahaya menggunakan suatu metode agar dapat diimplementasikan ke dalam sistem yang akan dibuat.

3. Menetukan Tujuan

Adapun target yang akan dituju dalam penelitian ini adalah mengimplementasikan sebuah metode ke dalam hardware Arduino yang dapat diterapkan ke dalam sistem intensitas cahaya lampu.

4. Mempelajari Literatur

literatur yang dipakai adalah jurnal-jurnal ilmiah, modul pembelajaran, buku tentang metode Fuzzy Logic, sensor dan transduser, dan mikrokontroler Arduino.

5. Mengumpulkan data

Untuk memperoleh data - data yang dibutuhkan dalam proses perancangan sistem ini, maka digunakanlah metode - metode sebagai berikut

- $\quad$ Studi kepustakaan (Library Research)

- Pengamatan (Observation)

- Dokumentasi 
6. Mendesain Sistem

tahap ini data yang dikumpulkan akan diolah dan diimplementasikan ke dalam sistem hardware dengan penerapan metode yang telah ditentukan. Desain sistem yang dimaksud berupa perencanaan serta perancangan prototipe.

7. Implementasi fuzzy logic

Dalam proses membangun sistem, penggunaan metode Fuzzy Logic akan diimplementasikan dalam dua sistem yaitu

- $\quad$ implementasi Fuzzy Logic ke dalam sistem mikrokontroler dengan bantuan beberapa alat dan software,

- $\quad$ Mengimplementasikan Fuzzy Logic ke dalam software Matlab di mana ini bertujuan untuk menguji coba hasil dari metode yang telah dimasukkan ke sistem alat.

8. Pengujian Hasil

Pada bagian ini hasil dari sistem prototipe yang telah dirancang akan diuji coba dan dibandingkan dengan peralatan yang dihasilkan oleh sistem nyata. Hal ini dilakukan untuk melihat hasil kinerja alat apakah sesuai dengan yang diharapkan.

9. Analisa Hasil

Hasil yang diperoleh dari ujicoba sistem kemudian akan dianalisa. Keakuratan data pada sistem harus sinkron yaitu perbandingan intensitas cahaya di dalam dan di luar ruangan laboratorium yang harus seimbang.

10. Pengambilan Keputusan

Setelah keseluruhan hasil uji coba dan analisa diperoleh tahap terakhir adalah pengambilan keputusan akan kelayakan sistem yang dirancang, sehingga dapat diimplementasikan langsung ke sistem yang sebenarnya.

3. ANALISA DAN HASIL

3.1. Algoritma Sistem

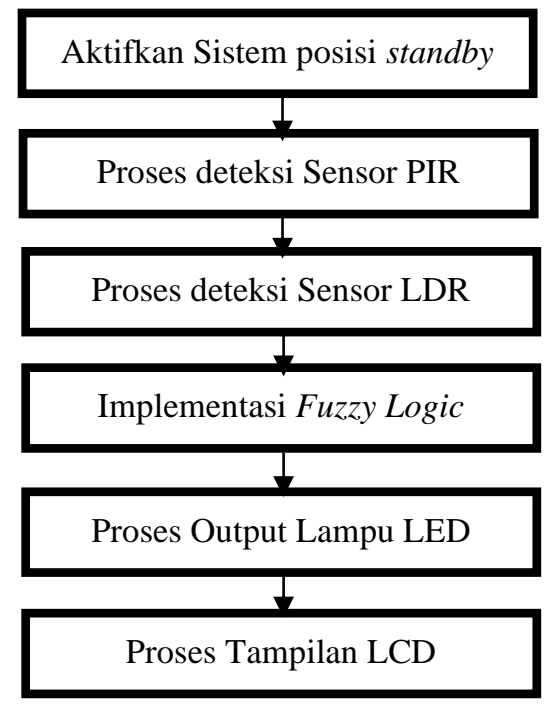

Gambar 2 : Algoritma sistem

Aliran proses dimulai dari pengaktifan sistem dan menempatkan dalam posisi standby. Lalu sistem akan membaca obyek pada sensor PIR, selanjutnya sistem akan membaca data pada sensor LDR Depan dan LDR belakang, dan lampu LED akan menyala tergantung dari perbandingan sensor LDR, selanjutnya hasil ditampilkan pada LCD. 


\subsection{Blog Diagram}

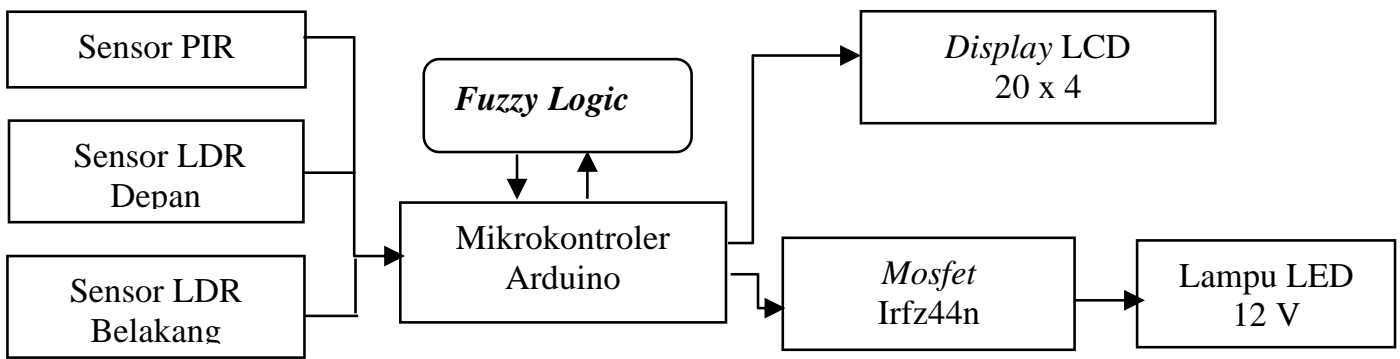

Gambar 3: Blog Diagram

Dari blok diagram sistem pengatur intensitas lampu selanjutnya dapat diuraikan fungsi dari masing - masing blok sebagai berikut

1. Sensor PIR / Passive Infrared

Sensor ini difungsikan pada alat untuk mengaktifkan sistem pada kondisi on dengan artian sebagai pengganti saklar on/off manual. Ketika ada objek manusia yang terdeteksi maka sistem aktif dan ketika objek manusia tidak terdeteksi maka sistem mati

2. Sensor LDR Bagian Depan dan Bagian Belakang

Sensor LDR atau biasa disebut sensor cahaya ini dirancang dua buah untuk menangkap perbandingan cahaya pagi, siang, sore dan malam di luar ruangan serta sensor ini diletakkan pada bagian depan dan belakang atap.

3. Mikrokontroler Arduino

Mikrokontroler Arduino pada alat berfungsi sebagai pemroses input dan output dari keseluruhan sistem pengatur intensitas cahaya yang berjalan, disini juga implementasi metode fuzzy logic dirancang.

4. Fuzzy Logic

Kecerdasan buatan yang nantinya ditanam kedalam chip mikrokontroler dengan rule - rule yang telah ditentukan. Fuzzy logic ini diimplementasikan pada pemrograman arduino.

5. Mosfet Irfz44n

Mosfet (Metal Oxide Semiconductor Field Effect Transistor) pada alat berfungsi sebagai driver lampu LED 12 Volt, dikarenakan mikrokontroler Arduino hanya menyuplay tegangan 5 volt maka dengan menambah Mosfet ini Lampu LED akan bekerja

6. Lampu LED 12 Volt

Lampu LED atau kepanjangannya Light Emitting Diode pada alat difungsikan sebagai output yaitu memancarkan intensitas cahaya gelap, redup, normal, sedang dan terang ke dalam ruangan.

7. Display LCD $20 \times 4$

Display LCD yang digunakan adalah tipe $20 \times 4$ pada alat difungsikan untuk menampilkan hasil dari pembacaan sensor, intensitas lampu LED dan kondisi rule if - then dari cahaya.

\subsection{Rangkaian Keseluruhan}

Rangakaian keseluruhan merupakan gabungan dari seluruh komponen. Pada gambar terlihat kombinasi komponen yang terhubung seperti sensor LDR depan dan belakang, sensor PIR , Lampu LED dan Display LCD 20x4 sebagai penampil hasil dari proses yang berjalan.

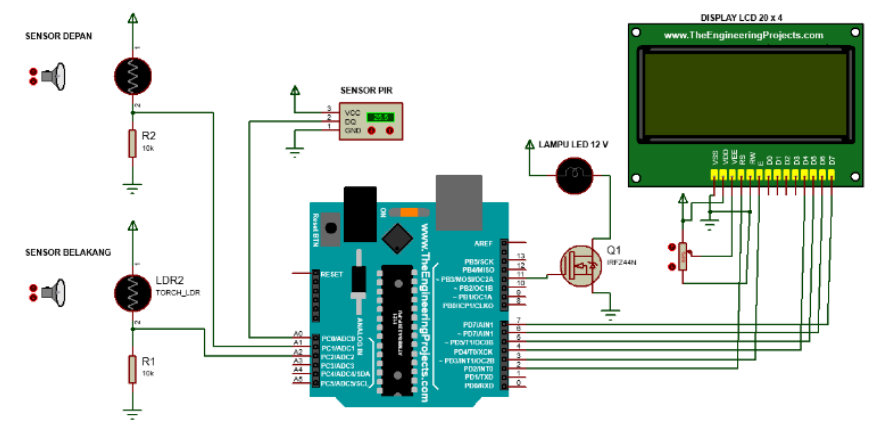

Gambar 4 : Rangkaian Keseluruhan 


\subsection{Implementasi Metode Fuzzy pada sistem}

Untuk pemisalan input yaitu untuk sensor depan 40 dan sensor belakang 65. berdasarkan kurva fuzzyfikasi maka dengan nilai sensor tersebut artinya Sensor depan yang memiliki nilai 40 berarti terletak pada variabel linguistik "AGAK GELAP" dan "REMANG - REMANG". Sedangkan sensor belakang nilai 65 terletak di dalam variabel linguistik "REMANG - REMANG" dan "AGAK TERANG".

1. Variabel sensor depan (AGAK GELAP), diketahui;

$$
\begin{array}{rrrr}
\text { A }=0 & \quad \mathrm{~b}=25 \quad \mathrm{c}=50 \quad \mathrm{x}=40 \quad \text { dikarenakan; } \mathrm{b}<\mathrm{x} \leq \mathrm{c} \\
\text { Maka; } & \\
Y^{*}= & \frac{(c-x)}{(c-b)} \\
Y^{*} & =\frac{(50-40)}{(50-25)} \\
Y^{*} & =\frac{10}{25}=0,4
\end{array}
$$

Dan grafik yang terbentuk antara lain :

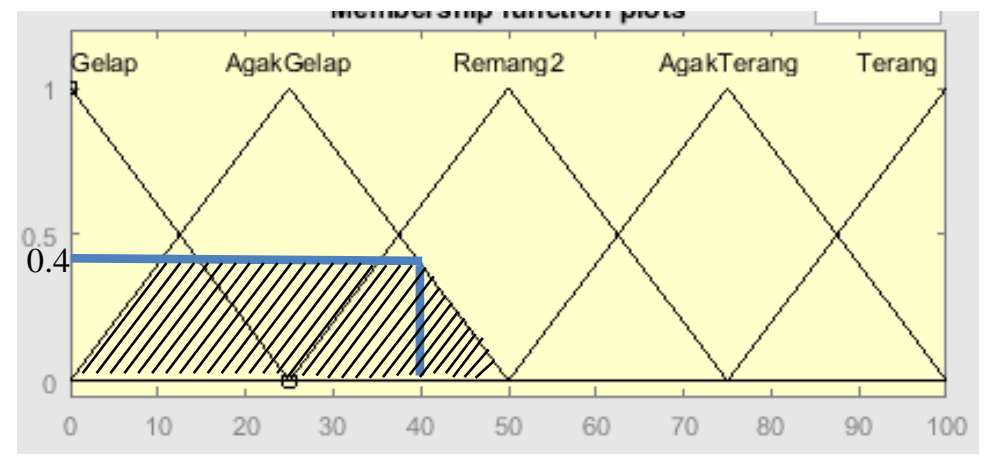

Gambar 5 Derajat Keanggotaan Sensor Depan pada Rule 1

Maka derajat keanggotaan untuk inputan kondisi 40 di dalam interval variabel AGAK GELAP sensor depan adalah 0,4 .

2. Variabel sensor depan (REMANG - REMANG), diketahui;

$$
\begin{aligned}
\text { A }=25 \quad \mathrm{~b} & =50 \quad \mathrm{c}=75 \quad \mathrm{x}=40 \quad \text { dikarenakan; } \mathrm{a}<\mathrm{x} \leq \mathrm{b} \\
\text { Maka; } & \\
Y^{*} & =\frac{(x-a)}{(b-a)} \\
Y^{*} & =\frac{(40-25)}{(50-25)} \\
Y^{*} & =\frac{15}{25}=0,6
\end{aligned}
$$

Dan grafik yang terbentuk antara lain:

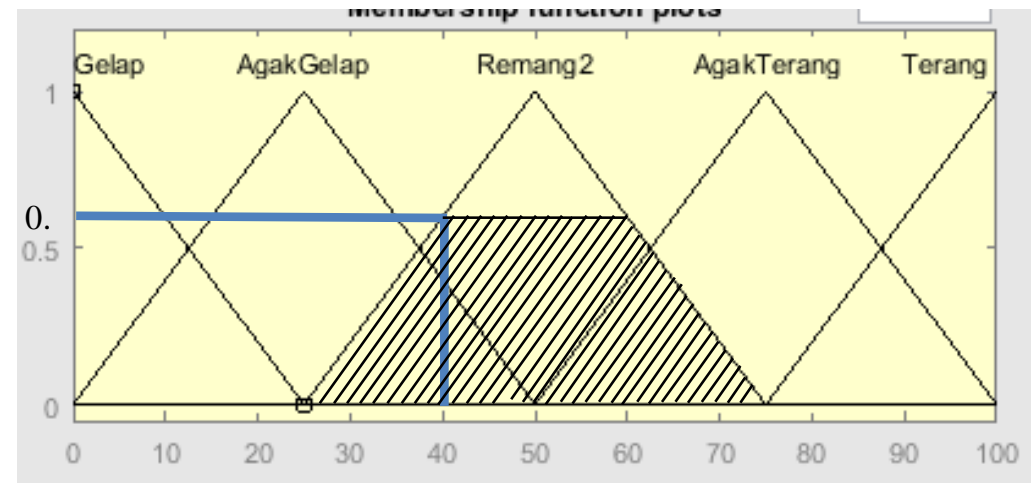

Gambar 6 Derajat Keanggotaan Sensor Depan Pada Rule 2 
Maka derajat keanggotaan untuk inputan kondisi 40 di dalam interval variabel REMANG REMANG sensor depan adalah 0,6.

3. Variabel sensor Belakang (REMANG - REMANG), diketahui;

$\begin{array}{llll}\mathrm{A}=25 & \mathrm{~b}=50 \quad \mathrm{c}=75 & \mathrm{x}=65 & \text { dikarenakan; } \mathrm{b}<\mathrm{x} \leq \mathrm{c}\end{array}$

Maka ;

$$
\begin{aligned}
Y^{*} & =\frac{(c-x)}{(c-b)} \\
Y^{*} & =\frac{(75-65)}{(75-50)} \\
Y^{*} & =\frac{10}{25}=0,4
\end{aligned}
$$

Dan grafik yang terbentuk antara lain:

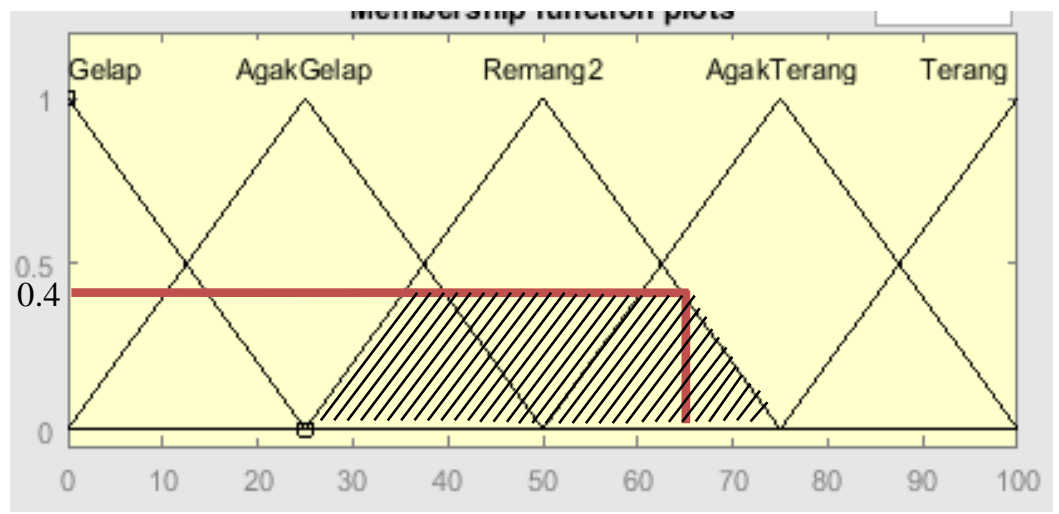

Gambar 7 Derajat Keanggotaan Sensor Belakang pada Rule 3

Maka derajat keanggotaan untuk inputan kondisi 65 di dalam interval variabel REMANG - REMANG sensor BELAKANG adalah 0,4.

4. Variabel sensor Belakang (AGAK TERANG), diketahui;

$\mathrm{A}=50$

$\mathrm{b}=75$

$\mathrm{c}=100 \mathrm{x}=65$ dikarenakan; $\mathrm{a}<\mathrm{x} \leq \mathrm{b}$

Maka ;

$$
\begin{aligned}
Y^{*} & =\frac{(x-a)}{(b-a)} \\
Y^{*} & =\frac{(65-50)}{(75-50)} \\
Y^{*} & =\frac{15}{25}=0,6
\end{aligned}
$$

Dan grafik yang terbentuk antara lain:

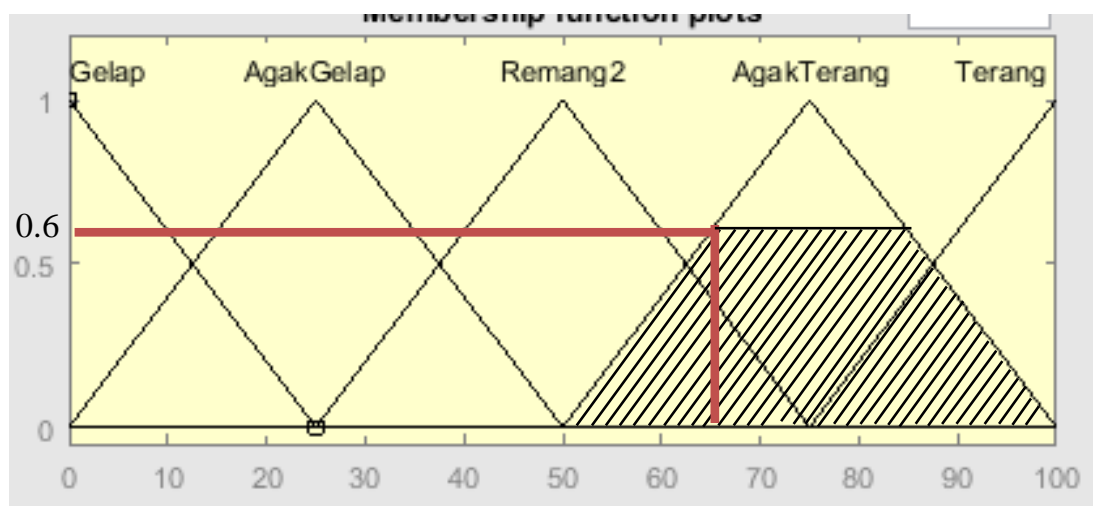

Gambar 8 Derajat Keanggotaan Sensor Belakang pada Rule 4

Maka derajat keanggotaan untuk inputan kondisi 65 di dalam interval variabel AGAK TERANG sensor BELAKANG adalah 0,6. 
Selanjutnya dari empat aturan fuzzy, berdasarkan tabel inferensi keseluruhan hanya rule 12, 13, 17 dan 18 yang digunakan. proses inferensi dilakukan dengan proses conjuction dan disjunction yaitu memilih derajat keanggotaan minimum atau maksimum. Pembahasan pada kasus menggunakan fungsi AND maka yang dicari adalah derajat keanggotaan minimum

1. If Sensor Depan = AGAK GELAP And Sensor Belakang = REMANG - REMANG Then, Lampu = SEDANG

$$
\alpha_{1}=\min \left(\mu_{S D_{\text {AgakGelap }}}[40], \mu_{S B_{\text {Remang }}}[65]\right)=\min (0.4,0.4)=0,4
$$

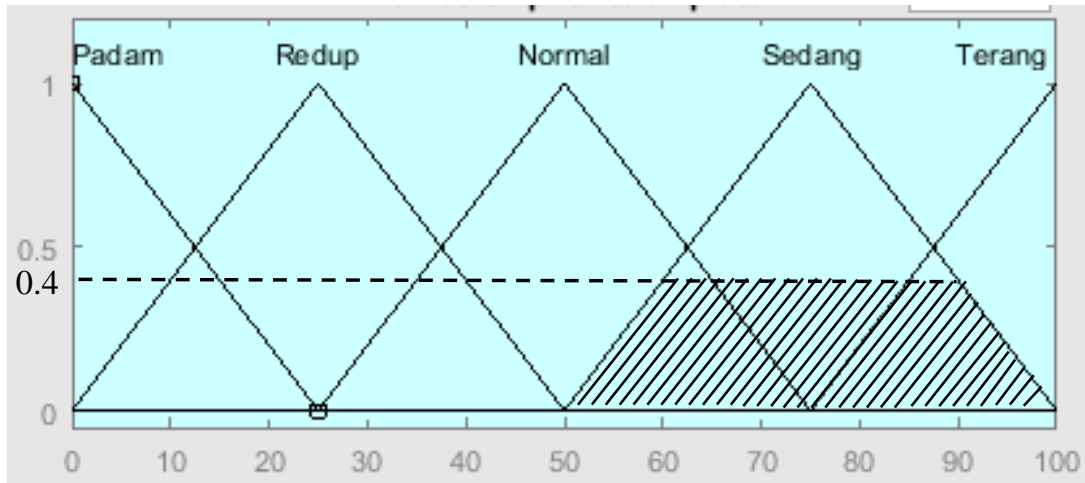

Gambar 9 Derajat Keanggotaan Lampu Pada Kurva Sedang 0,4

2. If Sensor Depan $=$ REMANG - REMANG And Sensor Belakang $=$ REMANG - REMANG Then, Lampu $=$ NORMAL

$$
\alpha_{1}=\min \left(\mu_{S D_{\text {Remang }}}[40], \mu_{S B_{\text {Remang }}}[65]\right)=\min (0.6,0.4)=0,4
$$

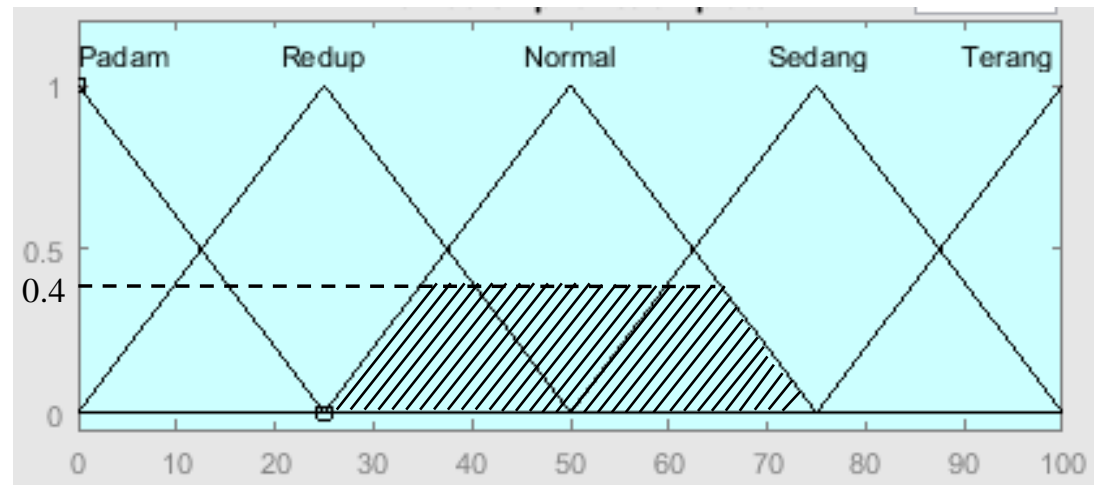

Gambar 10 Derajat Keanggotaan Lampu Pada Kurva Redup 0,4

3. If Sensor Depan $=$ AGAK GELAP And Sensor Belakang $=$ AGAK TERANG Then Lampu $=$ NORMAL

$$
\alpha_{1}=\min \left(\mu_{S D_{\text {AgakGelap }}}[40], \mu_{S B_{\text {AgakTerang }}}[65]\right)=\min (0.4,0.6)=0,4
$$

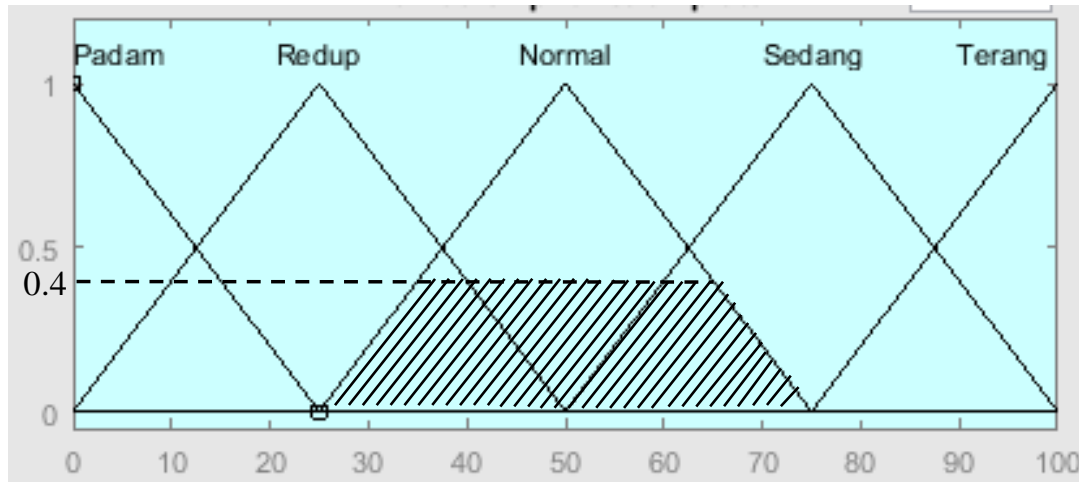

Gambar 11 Derajat Keanggotaan Lampu Pada Kurva Normal 0,4

4. If Sensor Depan $=$ REMANG - REMANG And Sensor Belakang = AGAK TERANG Then, Lampu = REDUP 


$$
\alpha_{1}=\min \left(\mu_{S D_{\text {Remang }}}[40], \mu_{S B_{\text {AgakTerang }}}[65]\right)=\min (0.6,0.6)=0,6
$$

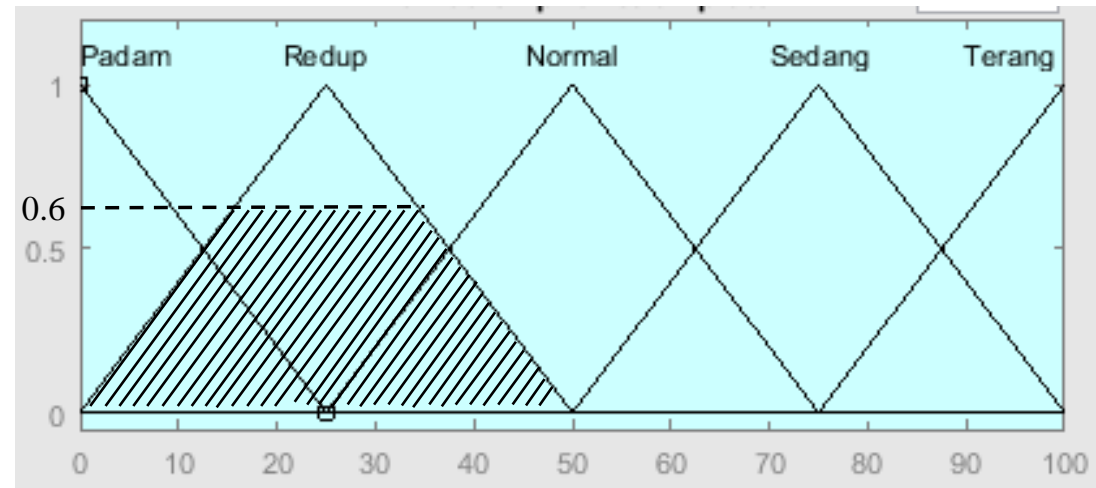

Gambar 12 Derajat Keanggotaan Lampu Pada Kurva Redup 0,6

Selanjutnya dari derajat keanggotaan minimum keempat rule fuzzy maka dapat dibentuk grafik composition untuk penentuan nilai tegas atau crisp dengan centroid method sebagai berikut.

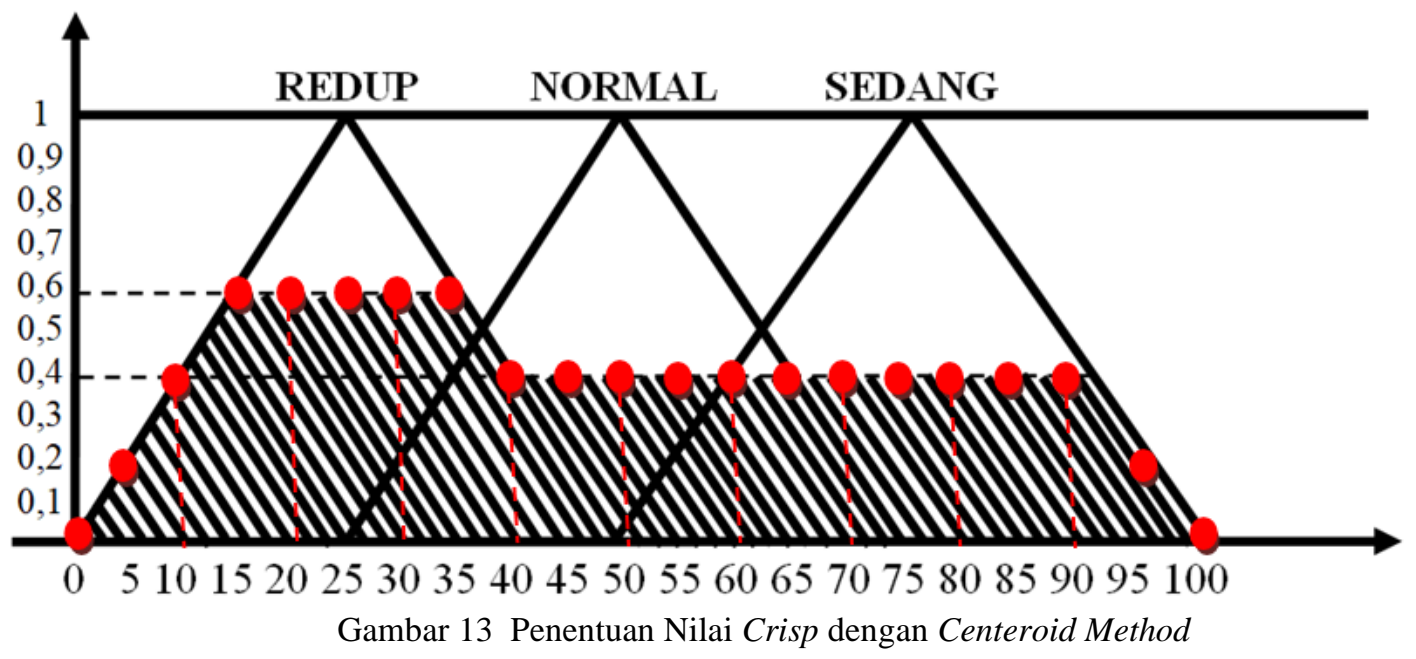

Titik - titik pada area grafik gambar 13 ditentukan secara berurut dari $051015 \ldots$ sampai 100. Dengan menggunakan persamaan centroid method maka diperoleh;

$(0 \times 0)+(5 \times 0,2)+(10 \times 0,4)+(15 \times 0,6)+(20 \times 0,6)+(25 \times 0,6)+(30 \times 0,6)+(35 \times 0,6)+$

$(40 \times 0,4)+(45 \times 0,4)+(50 \times 0,4)+(55 \times 0,4)+(60 \times 0,4)+(65 \times 0,4)+(70 \times 0,4)+(75 \times 0,4)+$

$(80 \times 0,4)+(85 \times 0,4)+(90 \times 0,4)+(95 \times 0,2)+(100 \times 0)$

$\mathrm{Y}^{*} \mathrm{COA}=$

$0+0,2+0,4+0,6+0,6+0,6+0,6+06+0,4+0,4+0,4+0,4+0,4+0,4+0,4+0,4+0,4+0,4+0,4+0,2+0$

$0+1+4+9+12+15+18+21+16+18+20+22+24+26+28+30+32+34+36+19+0$

$\mathrm{Y}^{*} \mathrm{COA}=$

$0+0,2+0,4+0,6+0,6+0,6+0,6+06+0,4+0,4+0,4+0,4+0,4+0,4+0,4+0,4+0,4+0,4+0,4+0,2+0$

$\mathrm{Y}^{*} \mathrm{COA}=\frac{385}{8,2}=46,95=47$

\subsection{Hasil dan Diskusi}

Pengujian menggunakan software MATLAB, dalam hal ini melihat perbandingan hasil akhir yang ditampilkan alat dan hasil uji coba menggunakan MATLAB. Pengujian dilakukan dengan menjalankan alat dan mencoba sensor dengan kondisi tertentu, selanjutnya nilai yang dibaca oleh sensor LDR depan dan sensor 
LDR belakang dimasukkan pada rule input MATLAB dan di ambil perbandingan dengan melhat hasil fuzzyfikasi output lampu di MATLAB dan hasil alat pada tampilan LCD nya.

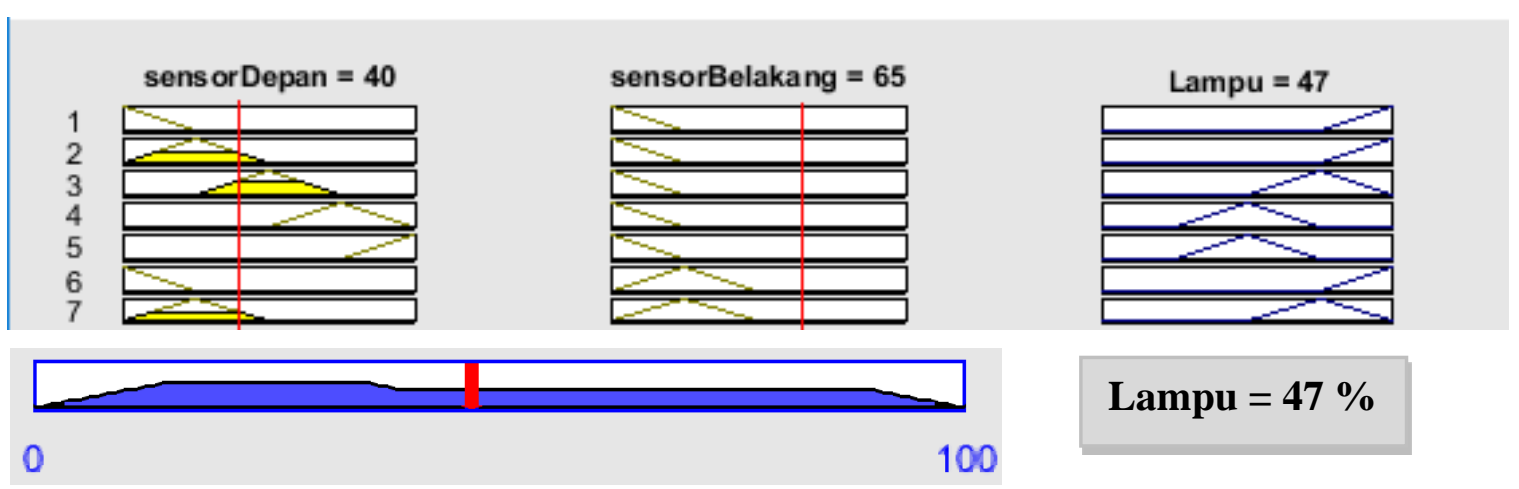

Gambar 14 Uji Coba Rule Menggunakan GUI Matlab

setelah didapat hasil ujicoba menggunakan MATLAB selanjutnya dilakukan ujicoba menggunakan system prototipe yang sudah dibuat, dengan nilai yang sama untuk bagian input yaitu sensor depan 40 dan sensor belakang 65 maka didapat output lampu sebesar $47 \%$.

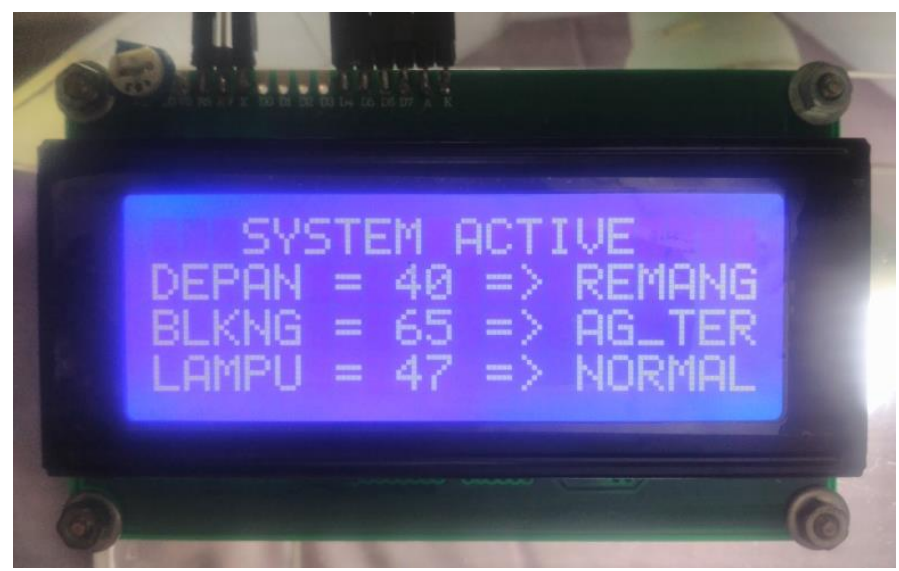

Gambar 15 Pengujian Menggunakan Alat

\section{KESIMPULAN}

Berdasarkan permasalahan yang ingin dipecahkan dan hasil pengujian alat yang dirancang, maka dapat diambil kesimpulan dari penelitian ini antara lain;

1. Metode Fuzzy Logic dapat berfungsi dengan baik digunakan untuk mencari nilai optimal pada rancang bangun sistem kendali intensitas lampu ruangan laboratorium.

2. Berdasarkan hasil uji coba, rancangan rangkaian dan pembangunan sistem kerja sensor, lampu dan mikrokontroler Arduino berjalan baik sesuai rancana awal.

3. Pemrograman bahasa $\mathrm{C}$ dapat diterapkan pada sistem kerja intensitas lampu dan baekerja dengan baik. Hal ini dapat dilihat dari kinerja alat yaitu intensitas lampu dapat berubah - ubah sesuai inputan dari sensor LDR.

\section{REFERENSI}

[1] Kaewwiset,T and Yodkhad,P(2017)," Automatic Temperature and Humidity control system by using Fuzzy Logic Algorithm for Mushroom nursery"IEEE 978-1-5090-5210-3/17/.

[2] Rohman,A. et al(2016)," Automation of Boiler Temperature and Water Level Control using Fuzzy Logic" IEEE 978-1-5090-0396-9/16/. 
[3] Koniar, D. et al(2017)," Design of a system for the brightness control of LEDs" IEEE 978-1-5090-64069/17/.

[4] Oltean,G and Ivanciu,LN(2017)," Implementation of a Fuzzy Logic-Based Embedded System for Temperature Control" IEEE 978-1-5386-0582-0/17/.

[5] Hangenbeck,E. et al(2016)," Using fuzzy logic in smart homes lighting controllers" IEEE 978-1-50902436-0/16/.

[6] Susilayati, "Cahaya di atas cahaya" Vol. 1, Nomor 2, Juli - Desember 2016

[7] T. Ganjar, Zulkarnain and Hermawan," Pengendali Intensitas Lampu Ruangan Berbasis Arduino UNO Menggunakan Metode Fuzzy Logic" Vol 7 (2), 2015

[8] Silvia, AI , Haritman E, and Muladi,Y(2014),'Rancang Bangun Akses Kontrol Pintu Gerbang Berbasis Arduino Dan Android" VOL.13, NO.1, MARET 2014, 1-10.

[9] Widyastuti M, Suwandi, Iskandar R F," Desain Dan Implementasi Sistem Kontrol Intensitas Lampu Motor Menggunakan Logika Fuzzy “e-Proceeding of Engineering : Vol.4, No.1 April 2017. 